\title{
Recognition of a subgroup of adolescents with rapidly growing thyroids under iodine-replete conditions: seven year follow-up
}

\author{
M Tajtáková, P Langer ${ }^{1}$, V Gonsorčíková, P Bohov ${ }^{1}$ and D Hančinová \\ First Clinic of Internal Medicine, Faculty of Medicine, P J Šafárik University, Košice, Slovakia and ${ }^{1}$ Institute of Experimental Endocrinology, Slovak \\ Academy of Sciences, Bratislava, Slovakia \\ (Correspondence should be addressed to P Langer, Institute of Experimental Endocrinology, 833 O6 Bratislava, Slovakia)
}

\begin{abstract}
Objective: To evaluate whether small iodine supplements decrease the incidence of adolescent thyroid hypertrophy in an iodine-sufficient population or whether such thyroid enlargement should be considered an inevitable physiological phenomenon.

Design: Beginning in September 1991 (after an initial examination in September 1990), 54 11-year-old children in Bardejov, Slovakia were given small iodine supplements (Thyrojod depot tablets containing $1530 \mu$ g iodide) every 2 weeks for 2 years followed by once weekly for 2 years. A second group of 63 children served as controls. In June 1995, there were still 52 treated and 60 control children in the study and these were examined; 44 treated and 48 control children remained in the study until June 1997. Methods: In 1990, 1993, 1995, 1996 and 1997 the thyroid volume (ThV) was measured by ultrasound. Serum levels of TSH, thyroglobulin, total and free thyroxine and tri-iodothyronine and anti-thyroid peroxidase (anti-TPO), anti-thyroglobulin (anti-TG) and anti-TSH receptor (TSR) antibodies were estimated in 1990 and 1994, while only TSH, and anti-TPO and anti-TSR antibodies were measured in 1997.

Results: There was no difference between the groups at any interval in the serum levels of the hormones measured. Marginally increased TSH was found in two treated and two control children. Anti-TSR antibodies were negative in all children, while anti-TPO and anti-TG antibodies were found in one treated and four control children. At the age of 10 years (1990), 84\% of all ThVs were less than $4 \mathrm{ml}$, indicating a previous life-long sufficient iodine intake. After the treatment was completed (June 1995), a significant difference in ThV $(P<0.04)$ was found between the whole treated $(5.78 \pm 0.19 \mathrm{ml})$ and the whole control group $(6.56 \pm 0.30 \mathrm{ml})$. However, there was already a marked difference in the 75 th percentile $(6.4 \mathrm{ml}$ in treated vs $8.5 \mathrm{ml}$ in controls) due to more rapid thyroid growth in certain children of the control group (ThV $>7.0 \mathrm{ml}$ in $6 / 52$ treated children vs $24 / 60$ controls; $P<0.01$ ).

Since such differences were much higher in 1997, the children in each group whose ThV was in the range of the upper $25 \%$ in 1997 were retrospectively evaluated as arbitrary separate subgroups in all the time intervals and compared with the remaining $75 \%$ of children who showed moderate thyroid growth rate. Two years after the termination of treatment (June 1997), excessive thyroid growth continued in the upper quarter of 12 controls with the highest ThV $\left(13.60 \pm 0.40 \mathrm{ml}\right.$ or $7.60 \pm 0.29 \mathrm{ml} / \mathrm{m}^{2} ; 12 / 12$ with ThV $>11.0 \mathrm{ml}$ ), and a similar subgroup now also appeared in 11 previously treated children $\left(10.79 \pm 0.51 \mathrm{ml}\right.$ or $6.19 \pm 0.30 \mathrm{ml} / \mathrm{m}^{2} ; 5 / 11$ with $\left.\mathrm{ThV}>11.0 \mathrm{ml}\right)$. At the same time, ThV in the remaining $75 \%$ of both control $\left(8.12 \pm 0.38 \mathrm{ml}\right.$ or $4.82 \pm 0.17 \mathrm{ml} / \mathrm{m}^{2} ; 3 / 36$ with $\left.\mathrm{ThV}>11.0 \mathrm{ml}\right)$ and treated $\left(7.20 \pm 0.30 \mathrm{ml}\right.$ or $4.39 \pm 0.17 \mathrm{ml} / \mathrm{m}^{2} ; 0 / 33$ with $\left.\mathrm{ThV}>11.0 \mathrm{ml}\right)$ children was significantly less $(P<0.01$ to $P<0.001)$ than that in the appropriate rapidly growing subgroups. During the whole observation period (1990-1997), no difference was found between treated and control subgroups with moderate thyroid growth.

Conclusions: Since iodine intake in Slovakia has been adequate for decades and sporadic iodine deficiency is highly unlikely, the observed excessive thyroid growth in certain adolescents may result from causes other than simple iodine deficiency (e.g. hereditary), which are nevertheless ameliorated by small iodine supplements. The question remains whether such a subgroup with rapidly growing thyroids should be included in the range of normal thyroid volumes in adolescents.
\end{abstract}

European Journal of Endocrinology 138 674-680

\section{Introduction}

During the last two decades, great efforts have been made to eradicate iodine deficiency $(1-3)$ and to ensure world-wide intake of the recommended dietary amount of iodine (4). Although exceptional global progress has been achieved, there are still several open questions, such as what is the optimum iodine intake for women of 
reproductive age and adolescents (4-6). In addition, the normal thyroid is still undefined from both the clinical point of view and that of molecular genetics. Such questions should probably be gradually answered by prospective small-scale studies.

We previously estimated by ultrasound the thyroid volumes (ThVs) of 4254 children and adolescents 6-18 years of age from 12 districts of Slovakia (7) and compared them with a population with a daily iodine intake of $200 \mu \mathrm{g}$, in whom the ThV was declared by WHO-UNICEF-ICCIDD to be normal $(8,9)$. In children below the age of $14(n=2120)$, ThVs were identical with those of the normal population, since only 3.01\% of values were slightly higher than the WHO 97 percentile level, but $9.04 \%$ of the 15-18-year-old Slovak adolescents $(n=2134)$ were above the WHO 97 percentile. Of 1174 iodine measurements in spot urine samples, $44 \%$ were above $10 \mu \mathrm{g} / \mathrm{dl}$ and thus in the normal range (10). European ThyroMobil Study investigators later found a median urinary iodine concentration of $13.0-14.3 \mu \mathrm{g} / \mathrm{dl}$ in 565 samples from four districts of Slovakia (11). On the basis of the above findings, it was suggested that, even with a presumed adequate but not excessive iodine intake, additional supplementation with small doses of iodine might prevent thyroid hypertrophy, which would otherwise occur in some adolescents because of excessive activation of molecular growth mechanisms in that particular fraction of the population. This study was therefore designed to evaluate whether small iodine supplements would decrease the incidence of adolescent thyroid hypertrophy in an iodine-sufficient population or whether such thyroid enlargement should be considered an inevitable physiological phenomenon.

\section{Patients and methods}

\section{Design, patients and history of the study}

The study was performed in one of four elementary schools of the district town of Bardejov (eastern Slovakia). All parents, children and teachers were informed of the purpose of the study and were kept abreast of information accumulated by the study at the meetings held by the investigators at least once a year. The parents of all participants gave their written informed consent.

The selected school was located in a large area of housing built in 1970-1980, to which the parents moved randomly from various suburbs and surrounding villages. After entering the school, the children were randomly allocated to one of four parallel classes according to the initial letter of their surname, so that in each parallel class almost the whole range of initial letters from A to Z was included. Two parallel classes were then allocated to the treatment group and the other two parallel classes to the untreated group. Only five parents of children allocated to the treatment group did not give their consent; their children were therefore moved to the control group.

At the age of 10 years (September 1990), 117 children ( 50 boys and 67 girls) had their initial examination (personal and family history with special respect to thyroid disease, physical examination, thyroid palpation and sonography). Urinary iodine and serum levels of hormones and antibodies were also measured, as listed below. There was no significant difference in the above parameters between the two groups.

Beginning in September 1991, tablets (Thyrojod Depot; Henning, Berlin, Germany) containing $1530 \mu \mathrm{g}$ iodide as KI were given to 54 children ( 22 boys and 32 girls) by their teachers. Because of the low body weight $(25-40 \mathrm{~kg})$ of these young children, the tablets were given every second Monday until the end of June 1993 (i.e. for 2 years). Since by then the body weight had increased to 40-55 kg, from July 1993 until June 1995 (i.e. for another 2 years) the same tablets were given every Monday, treatment during vacations being continued by parents. The control group consisted of 63 children ( 28 boys and 35 girls).

In June 1993, ThV was measured in 52 treated and 60 control children, and in June 1995 the same children (a few of them who were missed in June were examined in September 1995) were subjected to another thyroid examination. At this time they had completed elementary school, and 26 children did not continue in the study.

In June 1996 and June or September 1997 (one and two years after the termination of treatment), we were able to examine 44 treated and 48 control children, who had thus been continuously followed for 7 years.

In addition, to obtain basal information about ThV in the general population, 632 17-year-old adolescents ( 260 boys and 372 girls) were examined in four district towns of eastern Slovakia. In 134 of them, urinary iodine was estimated.

\section{Analytical methods}

Urinary iodine Spot urine samples were obtained before the start of the study (September 1990) and six times from January 1992 until June 1995 irregularly at 5 to 12 month intervals, each time on the 3rd day after the administration of Thyrojod. Alkaline ashing at $600 \pm 30^{\circ} \mathrm{C}$ followed by the Sandell-Kolthoff reaction and spectrophotometry were used (12). Results are expressed as $\mu \mathrm{g}$ iodine/dl urine.

In addition, urinary iodine in 134 spot urine samples obtained from the general population was kindly estimated by Professor F Vertongen (Department of Clinical Chemistry, University of Brussels, Brussels, Belgium) by the mild acid wet ash method followed by a similar colorimetric ceric ion arsenious acid reaction using a Technicon auto-analyser (11). 
Thyroid volume Thyroids were examined using a realtime instrument (AU 530; Esaote Biomedica, Florentia, Italy) with a $7.5 \mathrm{MHz}$ linear transducer. $\mathrm{ThV}$ for each lobe $(\mathrm{ml})$ was calculated according to the ellipsoid formula: width $(\mathrm{cm}) \times$ length $(\mathrm{cm}) \times$ thickness $(\mathrm{cm}) \times$ correction factor of $0.479(8,13)$.

Body surface area The body surface area was calculated by using the formula: (weight in $\mathrm{kg})^{0.425} \times$ (height in $\mathrm{cm})^{0.725} \times 71.84 \times 10^{-4}$.

Hormones and antibodies in serum Serum levels of all the hormones and antibodies listed below were measured in 1990 and 1994, but in 1997 only thyrotrophin (TSH) and anti-thyroid peroxidase (antiTPO) and anti-TSH receptor (TSR) antibodies (Abs) were analysed. All hormones and antibodies were measured with the appropriate RIA or IRMA kits kindly supplied by Brahms GmBH (Berlin, Germany). After each examination, the measurements were made in duplicate and in the same assay. Normal reference values were: TSH, 0.2-4.5 mU/l; thyroxine, $58-150 \mathrm{nmol} / \mathrm{l}$; tri-iodothyronine, $1.20-3.10 \mathrm{nmol} / \mathrm{l}$; free thyroxine, $10-25 \mathrm{pmol} / \mathrm{l}$; free tri-iodothyronine, 3.5-8.0 pmol/l; thyroglobulin, $<4 \mathrm{ng} / \mathrm{ml}$; anti-TPO Ab, $<200 \mathrm{U} / \mathrm{ml}$; anti-thyroglobulin (anti-TG) Ab, <200 U/ml; and anti-TSR Ab, <15 U/l. For all assays, the intra-assay variation was less than $5 \%$.

Statistical methods All results are given as mean \pm s.E. After normal distribution had been tested by the $\chi^{2}$ test, the differences between whole groups in the same time interval were evaluated by the non-parametric MannWhitney U-test. After the retrospective separation into subgroups, the differences between them were evaluated by ANOVA followed by multiple-range Bonferroni's test for each time interval separately.

The differences in frequency of individual $\mathrm{ThV}$ values over a certain cut-off level were tested by $\chi^{2}$.

\section{Results}

\section{Urinary iodine}

Before the start of the study (1990), mean urinary iodine for all the children was $9.13 \pm 0.74 \mu \mathrm{g} / \mathrm{dl}$ $(n=127)$. Cumulated data for all the urinary iodine estimations (using the alkaline dry ash method) in the treated group during 1991-1995 (21.02 $\pm 0.37 \mu \mathrm{g} / \mathrm{dl}$; $n=305)$ showed that, on the third day after Thyrojod administration, urinary iodine was consistently significantly higher $(P<0.001)$ than that in controls $(10.05 \pm 0.24 \mu \mathrm{g} / \mathrm{dl} ; n=341)$.

In the general adolescent population (using mild acid digestion), a median value of $14.1 \mu \mathrm{g} / \mathrm{dl}$ per 134 samples was found.

\section{ThV in the whole groups}

At the age of 10 years (1990), the volume of $84 \%$ of all thyroids was $<4.0 \mathrm{ml}$, which supports their life-long iodine-replete status. There was no difference between those allocated to the treated or control groups $(3.26 \pm 0.14 \mathrm{ml}$ in treated vs $3.08 \pm 0.15 \mathrm{ml}$ in controls or $2.68 \pm 0.10 \mathrm{ml} / \mathrm{m}^{2}$ body surface in treated vs $2.50 \pm 0.11 \mathrm{ml} / \mathrm{m}^{2}$ in controls), which supports the validity of the random selection. In addition, no difference in ThV was found between boys $(3.25 \pm$ $0.16 \mathrm{ml})$ and girls $(3.10 \pm 0.13 \mathrm{ml})$.

After the treatment had been completed (June 1995), $\mathrm{ThV}$ in the whole treated group was significantly lower than in the whole control group both in absolute terms $(5.78 \pm 0.19$ vs $6.56 \pm 0.30 \mathrm{ml} ; P<0.04)$ and adjusted for body size $\left(3.63 \pm 0.12\right.$ vs $4.17 \pm 0.16 \mathrm{ml} / \mathrm{m}^{2}$ respectively; $P<0.02)$.

The final evaluation in 1997 showed significantly lower ThV in the whole treated group than in the whole control group $(8.09 \pm 0.45$ vs $9.49 \pm 0.59 \mathrm{ml} \mathrm{respec-}$ tively, $P<0.02$, or $4.84 \pm 0.30$ vs $5.52 \pm 0.32 \mathrm{ml} / \mathrm{m}^{2}$ respectively, $P<0.05)$. At the same time, the increase in ThV (i.e. ThV in 1997 minus that in 1990) was significantly lower in the treated than in the control group $(4.86 \pm 0.32$ vs $6.49 \pm 0.41 \mathrm{ml}$ respectively, $P<0.004$, or $2.08 \pm 0.17$ vs $2.95 \pm 0.23 \mathrm{ml} / \mathrm{m}^{2}$ respectively, $P<0.003)$. Finally, even the number of children with ThV greater than $11.0 \mathrm{ml}$ was significantly lower $(P<0.001)$ in the treated $(5 / 44)$ than in the control group $(15 / 48)$.

\section{Thyroid volume in the separate subgroups}

After the treatment had been completed (June 1995), there was already a marked difference between the whole groups in the value of the 75 th percentile $(6.4 \mathrm{ml}$ in treated vs $8.5 \mathrm{ml}$ in controls), indicating more rapid thyroid growth in certain children of the control group. This was supported by the finding of $6 / 52$ in the treated group compared with $24 / 60$ in the control group with ThV greater than $7.0 \mathrm{ml}(P<0.01)$.

The examinations in 1996 and 1997 showed that, during the 2 year period after the termination of treatment, rapid thyroid growth in certain children continued, and this was not only in the control group, but a similar subgroup now appeared in the group previously treated with iodide. This showed that several individuals with distinctive thyroid growth characteristics existed among both the control and treated children.

Since the majority of larger thyroids was concentrated in the highest quarter of ThV values of each group, the children in each group whose ThV was in the range of the upper $25 \%$ in 1997 were retrospectively evaluated as arbitrary separate subgroups in all time intervals (Figs 1 and 2; groups A and C) and compared with the remaining $75 \%$ of children showing a moderate thyroid growth rate (Figs 1 and 2; groups B and D). 


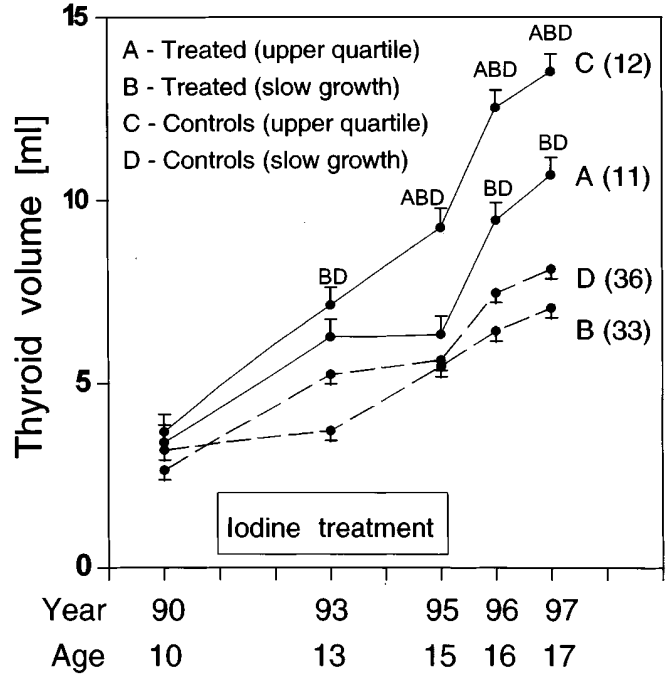

Figure 1 Absolute thyroid volumes $(\mathrm{ml})$ in subgroups of adolescents between 1990 and 1997 (means and S.E.). The differences between subgroups were evaluated separately by ANOVA followed by multiple-range Bonferroni's test for each time interval. lodine treatment was one tablet of Thyrojod depot containing $1530 \mu \mathrm{g}$ iodide every 2 weeks for 2 years followed by once weekly for 2 years. $\mathrm{A}, \mathrm{B}, \mathrm{C}, \mathrm{D}=P<0.01$ vs the subgroup designated by the indicated letter.

This retrospective evaluation (Figs 1 and 2) showed that, although being far from significant, already in 1990 mean ThV was slightly higher in subgroups A (five boys and six girls: $3.41 \pm 0.47 \mathrm{ml}$ or $2.96 \pm$ $0.30 \mathrm{ml} / \mathrm{m}^{2}$ ) and $\mathrm{C}$ (eight boys and four girls: $3.70 \pm$ $0.47 \mathrm{ml}$ or $3.13 \pm 0.30 \mathrm{ml} / \mathrm{m}^{2}$ ), which later showed more rapid thyroid growth than in subgroups $B$ (nine boys and 24 girls: $3.20 \pm 0.28 \mathrm{ml}$ or $\left.2.61 \pm 0.10 \mathrm{ml} / \mathrm{m}^{2}\right)$ and $\mathrm{D}(12$ boys and 24 girls: $2.65 \pm 0.27 \mathrm{ml}$ or $2.26 \pm 0.12 \mathrm{ml} / \mathrm{m}^{2}$ ) with moderate thyroid growth. Later the differences between the subgroups with rapid and moderate thyroid growth increased with time. Thus, at all time intervals the ThV in control subgroup $\mathrm{C}$ with rapid thyroid growth (1993: $7.15 \pm 0.47 \mathrm{ml}$ or $4.96 \pm 0.30 \mathrm{ml} / \mathrm{m}^{2} ; 1995$ : $9.20 \pm 0.45 \mathrm{ml}$ or $5.37 \pm 0.27 \mathrm{ml} / \mathrm{m}^{2} ; 1996: 12.55 \pm$ $0.51 \mathrm{ml}$ or $6.99 \pm 0.30 \mathrm{ml} / \mathrm{m}^{2}$; $1997: 13.60 \pm 0.49 \mathrm{ml}$ or $7.60 \pm 0.27 \mathrm{ml} / \mathrm{m}^{2}$ ) was consistently higher $(P<0.01)$ than that in subgroups $B$ and $D$ with moderate thyroid growth, while in 1995-1997 it was even higher $(P<0.05$ to $P<0.01)$ than that in treated subgroup A with rapid thyroid growth, which was, however, inhibited at the end of iodine treatment (1995). After the termination of treatment, the thyroid growth rate in the latter subgroup A increased, and ThV in $1996\left(9.40 \pm 0.53 \mathrm{ml}\right.$ or $\left.5.60 \pm 0.31 \mathrm{ml} / \mathrm{m}^{2}\right)$ and $1997\left(10.79 \pm 0.51 \mathrm{ml}\right.$ or $\left.6.19 \pm 0.30 \mathrm{ml} / \mathrm{m}^{2}\right)$ was higher than in subgroups $\mathrm{B}(P<0.01)$ and $\mathrm{D}(P<0.05$ to $P<0.01$ ), which represent the lower $75 \%$ of ThVs for treated and control children respectively, between

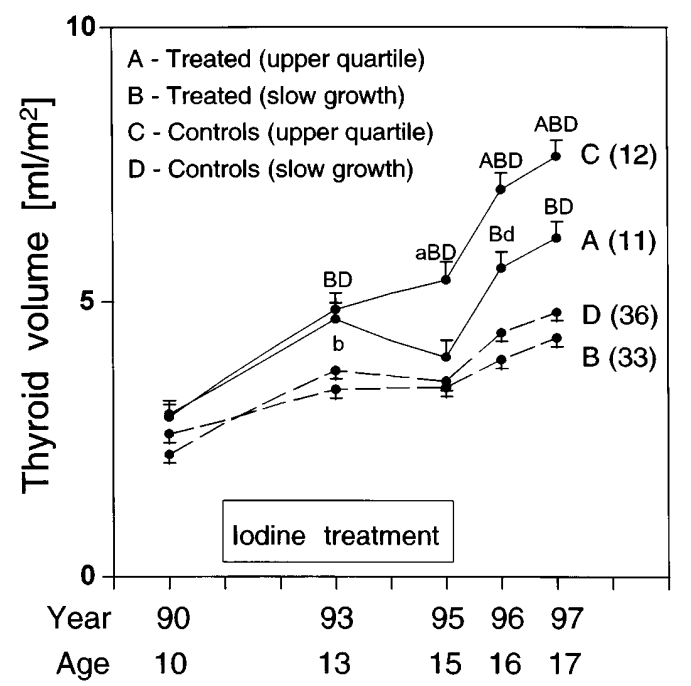

Figure 2 Relative thyroid volumes $\left(\mathrm{ml} / \mathrm{m}^{2}\right.$ body surface) in subgroups of adolescents between 1990 and 1997 (means and S.E.). lodine treatment was one tablet of Thyrojod depot containing $1530 \mu \mathrm{g}$ iodide every 2 weeks for 2 years followed by once weekly for 2 years. The differences between subgroups were evaluated separately by ANOVA followed by multiple-range Bonferroni's test for each time interval. $\mathrm{A}, \mathrm{B}, \mathrm{C}, \mathrm{D}=P<0.01$ vs the subgroup designated by the indicated letter; a, b, c, $\mathrm{d}=P<0.05$ vs the subgroup designated by the appropriate large letter.

which no significant differences were found during the whole observation period.

The final evaluation in 1997 showed that the difference in $\mathrm{ThV}$ between the upper $25 \%$ and the remaining $75 \%$ was significant for both the previously treated children (A: $10.79 \pm 0.51 \mathrm{ml}$ vs B: $7.20 \pm$ $0.29 \mathrm{ml}, P<0.01$ or A: $6.19 \pm 0.30 \mathrm{ml} / \mathrm{m}^{2}$ vs B: $4.39 \pm$ $0.17, P<0.01)$ and for controls $(\mathrm{C}: 13.60 \pm 0.40 \mathrm{ml}$ vs D: $8.12 \pm 0.28 \mathrm{ml}, P<0.01$ or $\mathrm{C}: 7.60 \pm 0.29 \mathrm{ml} / \mathrm{m}^{2}$ vs D: $4.82 \pm 0.17, P<0.01)$. Similarly, the number of children with $\mathrm{ThV}$ greater than $11.0 \mathrm{ml}$ was higher $(P<0.001)$ in subgroups with rapid thyroid growth than that in the respective subgroups with moderate thyroid growth (for previously treated $5 / 11$ vs $0 / 33$ and for controls $12 / 12$ vs 3/36).

\section{ThV in the general population}

The ThV (all values in this section are $\mathrm{ml} / \mathrm{m}^{2}$ ) in 632 17-year-old adolescents (4.84 \pm 0.07$)$ was not different from that in 92 adolescents of the same age participating in this study $(5.19 \pm 0.15)$, which shows that the latter group, although less numerous, was typical of the general population. This was further supported by similar ThV values in the upper $25 \%$ of the general population $(7.32 \pm 0.12, n=158)$ and the participants of this study $(6.92 \pm 0.26, n=23)$, the same being true for the remaining $75 \%(4.37 \pm 0.05(n=474)$ vs $4.61 \pm 0.15(n=69)$ respectively). This also shows 
that, even in the general population, a subgroup with an increased thyroid growth rate may exist.

In the general population, the $\mathrm{ThV}$ in 372 girls $(5.30 \pm 0.09)$ was higher $(P<0.01)$ than that in 260 boys $(4.83 \pm 0.09)$. The values found in this study (see below) were in the same range, and no significant difference was found either between all the boys and girls $(5.35 \pm 0.31 \quad(n=34)$ vs $5.10 \pm 0.23(n=58)$ respectively) or between treated $(4.97 \pm 0.38(n=14)$ vs $4.78 \pm 0.16(n=30)$ respectively $)$ or control boys and girls $(5.62 \pm 0.24(n=20)$ vs $5.45 \pm 0.38(n=28)$ respectively), suggesting that sex differences were inconsequential.

\section{Hormone levels}

No significant differences in serum TSH, thyroglobulin, total and free thyroxine and tri-iodothyronine concentrations were found at any time between boys and girls, irrespective of whether they were in the treated or control group, and all were in the normal range (Table 1). However, at the age of 15 years, a marginally increased TSH level was found in two treated children (4.9 and $5.4 \mathrm{mU} / \mathrm{l})$ and in two controls (4.7 and $7.2 \mathrm{mU} / \mathrm{l})$, but their thyroid hormone levels and ultrasound findings were within the normal range. An increased level of anti-TG Ab was found only in one of them. In all children still in the study in 1997, the TSH level was within the normal range.

\section{Thyroid autoantibodies}

During the whole observation period, anti-TSR Ab was negative in all children. Positive anti-TPO and anti-TG reactions were found in one girl destined for the control group at the age of 10 years and, at the age of 15 in another two control girls, one control boy and one treated girl. In all the above cases, the hormone levels (except for the one boy with a TSH of $5.4 \mathrm{mU} / \mathrm{l}$ ), ThV and ultrasound findings were within the normal range. In 1997, positive anti-TPO reactions were found in four control children (three girls and one boy) and one previously treated girl, only one control girl being newly positive.

\section{Discussion}

The administration of $1530 \mu \mathrm{g}$ iodide at weekly intervals appears to be appropriate for a long-term study. Our findings of increased urinary iodine on the third day after Thyrojod administration are in agreement with those showing increased urinary iodine on the second and third days after administration of $1500 \mu \mathrm{g}$ iodide (14). In addition, the same urinary iodine per week was found after a single dose of $1500 \mu \mathrm{g}$ iodide or a daily dose of $200 \mu \mathrm{g}$ iodide for 7 days (14). Most of the remaining third of the administered iodine presumably accumulated in the thyroid. Administration of $1000 \mu \mathrm{g}$ iodide once weekly for 6 weeks produces an increase in intrathyroidal iodine, as estimated by X-ray fluorescence (15).

In a 4 year study of children, who were initially 10 years old, in iodine-deficient areas of Germany, Hintze et al. (16) compared 146 children who used iodized salt with 188 children who used non-iodized salt. Although they found increased urinary iodine from the use of iodized salt, they did not use sonography and they could not demonstrate any decrease in palpable goitre prevalence. Leisner et al. (17) observed 46 13-year-old children with an initial average ThV of $26.4 \mathrm{ml}$, about 5 times higher than in our study. After 4-8 months of daily supplementation with $100 \mu \mathrm{g}$ iodide, ThV decreased to an average of $16.6 \mathrm{ml}$. In three groups of 30 children (age 13-15 years), Einenkel et al. (18) studied the effects of daily oral iodide $(150 \mu \mathrm{g})$, thyroxine $(100 \mu \mathrm{g})$ or a combination of $100 \mu \mathrm{g}$ iodide plus $50 \mu \mathrm{g}$ thyroxine. After 6 months, ThV decreased from the average respective values of $18.5,14.1$ and $17.2 \mathrm{ml}$ to $8.8,8.3$ and $8.3 \mathrm{ml}$.

However, the aim of our study differed from those presented above for the following reasons. (1) It was not designed to treat developed goitres, but rather to prevent the excessive thyroid growth that we previously found to occur in about $10 \%$ of adolescents (7). (2) It was performed in a country with an adequate basal dietary intake of iodine since the early 1950 s, established by the mandatory consumption of iodized salt (19) produced by a single state factory and an embargo against importation of any other salt, the actual concentration of iodine in the salt being monitored by approximately

Table 1 Overview of hormone levels found in 1994 (means \pm S.E.).

\begin{tabular}{|c|c|c|c|c|}
\hline \multirow[b]{2}{*}{ Parameter } & \multicolumn{2}{|c|}{ Boys } & \multicolumn{2}{|c|}{ Girls } \\
\hline & $\begin{array}{l}\text { Treated } \\
(n=22)\end{array}$ & $\begin{array}{c}\text { Control } \\
(n=28)\end{array}$ & $\begin{array}{l}\text { Treated } \\
(n=32)\end{array}$ & $\begin{array}{l}\text { Control } \\
(n=35)\end{array}$ \\
\hline $\mathrm{TSH}(\mathrm{mU} / \mathrm{l})$ & $2.11 \pm 0.16$ & $2.15 \pm 0.18$ & $2.26 \pm 0.18$ & $2.11 \pm 0.14$ \\
\hline $\mathrm{TT}_{4}(\mathrm{nmol} / \mathrm{l})$ & $121.3 \pm 5.39$ & $114.7 \pm 4.07$ & $111.3 \pm 3.68$ & $120.6 \pm 2.94$ \\
\hline $\mathrm{TT}_{3}(\mathrm{nmol} / \mathrm{l})$ & $2.08 \pm 0.08$ & $2.07 \pm 0.09$ & $1.93 \pm 0.09$ & $1.96 \pm 0.09$ \\
\hline $\mathrm{FT}_{4}(\mathrm{pmol} / \mathrm{l})$ & $15.8 \pm 0.72$ & $14.8 \pm 0.69$ & $15.9 \pm 0.45$ & $15.5 \pm 0.46$ \\
\hline $\mathrm{FT}_{3}(\mathrm{pg} / \mathrm{ml})$ & $7.00 \pm 0.29$ & $6.92 \pm 0.10$ & $6.80 \pm 0.15$ & $6.67 \pm 0.13$ \\
\hline Thyroglobulin (ng/ml) & $6.86 \pm 1.04$ & $4.93 \pm 0.99$ & $7.96 \pm 1.18$ & $6.84 \pm 1.16$ \\
\hline
\end{tabular}

$\mathrm{TT}_{4}$ and $\mathrm{FT}_{4}$, total and free thyroxine; $\mathrm{TT}_{3}$ and $\mathrm{FT}_{3}$, total and free tri-iodothyronine. 
1000 analyses a year of salt samples from the distribution network performed by public health laboratories. This is supported by the low ThV in 4254 Slovak children in our previous study (7) and by similar low volumes found in Slovakia by the European ThyroMobil Project 1994/95 (11), confirming that the iodine prophylaxis had been efficacious $(7,11,19-22)$. (3) Urinary iodine excretion also indicated an adequate iodine intake. This is mainly supported by the data of the European ThyroMobil Campaign 1994/95 (11), in which median urinary iodine values of $12-13 \mu \mathrm{g} / \mathrm{dl}$ in various districts of Slovakia were obtained by a method using mild acid digestion at $130{ }^{\circ} \mathrm{C}$ and by the estimations of urinary iodine in the general adolescent population made by the same method, which gave a median value of $14.1 \mu \mathrm{g} / \mathrm{dl}$. In contrast, our data in this study were obtained by a method using alkaline ashing at $600 \pm 30{ }^{\circ} \mathrm{C}$, which gives up to about a $30 \%$ loss of iodine and after the recommended appropriate correction (which was not used in this study) would give values in the optimal range (10).

The iodine-replete status of the children in our present study is strongly supported by the low mean ThV values in the groups with slowly growing thyroids (Figs 1 and 2, groups B and D). Thus, ThV in the majority of both treated and control groups did not differ in either absolute or relative terms and was in close agreement with the medians of recently recommended normative values $(11,23)$. The negligible difference in ThVs between the majority of treated and control children further supports their iodine-replete status.

However, significant differences were found between the ThV of the highest $25 \%$ of children and the remaining children of both groups. The average ThV of the rapidly growing control thyroids was about $70 \%$ (Fig. 1) or $50 \%$ (Fig. 2) higher than that in slowly growing control thyroids, while the corresponding difference for the treated group was about 50\% (Figs 1 and 2). Presumably, if the treated group had not been treated, the final distribution of ThVs in this group would be the same as in the controls. The clusters of increased values therefore probably represent subgroups with an increased thyroid growth potential, which was kept in check in the majority of treated children by iodine supplementation. We therefore postulate that adolescent thyroids should not be considered a homogeneous group, since there is at least one subgroup that may be characterized by more rapid thyroid growth. As shown, this rapid growth was inhibited by long-term supplementation with iodine, but continued after the supplementation had been withdrawn.

From this epidemiological field survey alone, we cannot derive a definite explanation for the observed differences in thyroid growth rate, which may be related to variations in the individual tuning of molecular growth mechanisms, probably of hereditary origin.
However, the data suggest that increased iodine intake may partly ameliorate the excessive growth or, alternatively, that some thyroids require more iodine to keep their growth rate closer to that of the majority.

As explained above, the iodine intake in Slovakia has been adequate for several decades, and individual or sporadic iodine deficiency is highly unlikely. We therefore assume that the increased growth rate of certain thyroids results from causes other than iodine deficiency, possibly based on individual genetic background. However, the question remains whether the particular subgroup identified in this study should be considered 'normal' and thus included in the recently recommended range of normal thyroid volume in adolescents $(11,23)$.

\section{Acknowledgements}

The authors wish to express their gratitude to Henning Berlin, GmBH and Brahms GmBH (Berlin, Germany) for supporting this study and to Ekkehard Scheiffele, MD for his continuing interest. The additional support of the UN Children's Fund (Geneva) granted in 1995 through the Slovak Committee for UNICEF (Bratislava) and the personal interest of $\mathrm{Mr}$ Edmond McLoughney are gratefully appreciated. The study was also partly supported by the Ministry of Education of the Slovak Republic (grant no. 1/990549/92) and the Slovak Grant Agency for Science (GAV no. 2/543/93). We thank also Monte A Greer, MD (Portland, Oregon, USA) for critical reading of the manuscript and improving the English.

\section{References}

1 Hetzel BS. An overview of the prevention and control of iodine deficiency disorders. In The Prevention and Control of Iodine Deficiency Disease, pp 7-31. Eds BS Hetzel, JT Dunn \& JB Stanbury. Amsterdam: Elsevier, 1987.

2 Gutekunst R \& Scriba P. Goiter and iodine deficiency in Europe. The European Thyroid Association report as updated in 1988. Journal of Endocrinological Investigation 198912 209-220.

3 Delange F. The disorders induced by iodine deficiency. Thyroid 19944 107-128.

4 Delange F. Requirements of iodine in humans. In Iodine Deficiency in Europe: A Continuing Concern, pp 5-16. NATO ASI, Series A: Life Sciences vol 241. New York: Plenum Press, 1993.

5 Boyages SC. Iodine deficiency disorders. Journal of Clinical Endocrinology and Metabolism 199377 587-591.

6 Laurberg P. Editorial: Iodine intake - what are we aiming at? Journal of Clinical Endocrinology and Metabolism 199479 17-19.

7 Langer P, Tajtáková M, Podoba J Jr, Košt’álová L' \& Gutekunst R. Thyroid volume and urinary iodine in school children and adolescents in Slovakia after 40 years of iodine prophylaxis. Experimental and Clinical Endocrinology 1994102 394-398.

8 Gutekunst R \& Teichert HM. Requirements for goitre surveys and the determination of thyroid size. In Iodine Deficiency in Europe: A Continuing Concern, pp 109-118. Eds F Delange, JT Dunn \& D Glinoer. NATO ASI, Series A: Life Sciences vol 241. New York: Plenum Press, 1993.

9 Delange F. Iodine deficiency in Europe. Thyroid International (Merck) 19943 3-18 
10 Dunn JT \& van der Haar F. A Practical Guide to the Correction of Iodine Deficiency. Charlottesville: ICC/IDD, University of Virginia, 1990.

11 Delange F, Benker G, Caron Ph, Eber O, Ott W, Pieter F et al. Thyroid volume and urinary iodine in European schoolchildren: standardization of values for assessment of iodine deficiency. European Journal of Endocrinology 1997136 180-187.

12 Dunn JT, Crutchfield HE, Gutekunst R \& Dunn D. Methods for Measuring Iodine in Urine. Charlottesville: ICC/IDD, University of Virginia, 1993.

13 Brunn J, Block U, Ruf G, Bos I, Kunye WP \& Scriba PC. Volumetrie der Schilddrüsenlappen mittels real-time Sonographie. Deutsche Medizinische Wochenschrift 1981106 1138-1140.

14 Breidt M. Die renale Jodausscheidung unter der Einnahme von $200 \mu \mathrm{g}$ Iodid täglich oder $1500 \mu \mathrm{g}$ wöchentlich. Thesis. Tübingen Faculty of Medicine, Eberhard Karls University, 1991.

15 Jonckheer MH, Michotte Y, van Steirteghem AC \& Deconinck F. The adaptation of the human thyroid gland to a physiological regimen of iodide intake: evidence for a transitory inhibition of thyroid hormone secretion modulated by the intrathyroida iodine stores. Journal of Endocrinological Investigation 19836267 272.

16 Hintze G, Emrich D, Richter K, Thal H, Wasielewski T \& Köbberling J. Effect of voluntary intake of iodinated salt on prevalence of goitre in children. Acta Endocrinologica (Copenhagen) $1988198333-338$

17 Leisner B, Henrich B, Knorr D \& Kantlehner R. Effect of iodide treatment on iodine concentration and volume of endemic non/toxic goitre in childhood. Acta Endocrinologica (Copenhagen) $198510844-50$

18 Einenkel D, Bauch KH \& Benker G. Treatment of juvenile goitre with levothyroxine, iodide or a combination of both: the value of ultrasound grey-scale analysis. Acta Endocrinologica (Copenhagen) $1992127301-306$.

19 Podoba J. Endemic Goitre in Slovakia (in Slovak). Bratislava: Veda, 1962.

20 Langer P. Eastern and southeastern Europe. In Endemic Goitre and Endemic Cretinism, pp 144-153. Eds JB Stanbury \& BS Hetzel. New York: John Wiley, 1980.

21 Langer P, Tajtáková M, Podoba J, Zamrazil V, Pohunková D, Bednár J et al. Some problems of endemic goiter in CzechoSlovakia yesterday, today and tomorrow. In Iodine deficiency in Europe: A Continuing Concern, pp 353-358. Eds F Delange, JT Dunn \& D Glinoer. NATO ASI, Series A: Life Sciences vol 241. New York: Plenum Press, 1993.

22 Tajtáková M, Hançinová D, Langer P, Tajták J, Földes O, Malinovský $\mathrm{E}$ et al. Thyroid volume by ultrasound in boys and girls $6-16$ years of age under marginal iodine deficiency as related to the age of puberty. Klinische Wochenschrift 199168 503-506.

23 WHO/ICCIDD: Recommended normative values for thyroid volume in children aged 6-15 years. Bulletin of the World Health Organization 199775 95-97.

Received 31 October 1997

Accepted 9 February 1998 